\title{
KARAKTERISTIK FENOTIPE BEBERAPA SIFAT KUANTITATIF AYAM KAMPUNG DI MINAHASA
}

\author{
Ezri S. S. Milas, Josephine L. P. Saerang, Lucia J. Lambey, Ben J. Takaendengan
}

Fakultas Peternakan Universitas Sam Ratulangi, Manado 95115

\begin{abstract}
ABSTRAK
Penelitian ini bertujuan untuk mendapatkan ukuran dari karakter fenotipik pada sifat kuantitatif ayam kampung di Minahasa, Sulawesi Utara. Diharapkan penelitian ini menjadi tambahan informasi mengenai karakter kuantitatif ayam kampung di Minahasa sebagai salah satu acuan dalam usaha pelestarian sumber daya genetik (SDG) baik untuk pengembangan ayam kampung dan tujuan pemuliaan lainnya. Materi yang digunakan adalah 291 ekor ayam kampung jantan dan betina yang telah dipisahkan berdasarkan umur ( 6 bulan ke atas) dan telah mencapai dewasa kelamin di Kabupaten Minahasa. Metode Penelitian yang digunakan adalah analisis deskriktif (rataan, standar deviasi, koefisien keragaman dan korelasi) dan dilanjutkan dengan uji-t. Pengambilan data dengan cara pengamatan dan pengukuran langsung terhadap sifat kuantitatif berdasarkan parameter yang diamati. Hasil penelitian ini memberi gambaran karakter fenotipik sifat kuantitatif ayam kampung jantan dan betina di Minahasa dimana ukuran PF (panjang femur) dan PS (panjang sayap) ternyata tidak berbeda atau sama pada kedua jenis kelamin. LS (lingkar shank) dan PP (panjang paruh) berbeda nyata $(\mathrm{P}<0,05)$, sedangkan sifat kuantitatif PT (panjang tibia), PTS (panjang shank), PJK (panjang jari ketiga), TJ (tinggi jengger) menunjukan perbedaan sangat nyata $(\mathrm{P}<0,01)$. Kesimpulan sifat - sifat kuantitatif ayam
\end{abstract}

*Korespondensi (Corresponding author)

Email: pinky_saerang@yahoo.com kampung jantan dan betina di Minahasa masih sangat beragam dan berkorelasi dari tinggi dampai rendah.

Kata kunci : ayam kampung, fenotipe, sifat kuantitatif.

\section{ABSTRACT}

\section{PHENOTYPE CHARACTERISTICS OF SOME QUANTITATIVE TRAITS OF NATIVE CHICKEN IN} MINAHASA. This study aims to obtain a measure of the phenotypic character of the quantitative traits of native chickens in Minahasa, North Sulawesi. This research was useful as additional information about the quantitative character of native chickens in Minahasa as a reference in efforts to preserve genetic resources (SDG) both for the development of native chickens and other breeding purposes. The material used was 291 male and female native chickens that had been separated by age ( 6 months and above) and had reached adult sex in the Minahasa Regency. The research method used was descriptive analysis (average, standard deviation, coefficient of variation and correlation) and continued withT-test. Retrieval of data by direct observation and measurement of quantitative properties based on the observed parameters. The results of this study illustrate the phenotypic character of quantitative traits of male and female native chickens in Minahasa where the size of the FL (femur length) and WL (wing length) were not different or the same in both sexes. SC (shank circumference) and CL (comb length) were significantly different 
$(\mathrm{P}<0.05)$, while the trait of TL (tibia length), SL (shank length), TFL (third finger length), $\mathrm{CH}$ (comb height) showed differences very significant $(\mathrm{P}<0.01)$. It can be concluded quatitavive characteristics of native chicken in Minahasa were diverse and correlate from high to low.

Keywords: native chicken, phenotype, quantitative characteristics.

\section{PENDAHULUAN}

Ayam kampung merupakan salah satu jenis ternak unggas yang paling banyak menyebar di Indonesia dan didefinisikan sebagai ayam yang tidak mempunyai ciri spesifik yang khas, dengan kata lain memiliki genotipe dan fenotipe yang masih beragam (Sartika 2016). Ayam kampung berpotensi tinggi untuk pengembangan peternakan dengan cara pemeliharaan yang sederhana dan modal yang sangat rendah sehingga peternak dapat mengembangkan ayam kampung secara tradisional dan turuntemurun (Nataamijaya, 2000). Sifat kuantitatif merupakan sifat yang dapat diukur dengan alat ukur dan sifat ini dipengaruhi oleh banyak pasangan gen dan juga dipengaruhi oleh faktor lingkungan (Kurnianto, 2009). Masyarakat yang ada di Minahasa memelihara ayam kampung sebagai ternak penghasil telur dan daging untuk dikonsumsi untuk memenuhi kebutuhan sehari-hari baik untuk hari raya maupun sebagai tabungan dan lain-lain dengan sistem pemeliharaan yang masih tradisional dan umumnya kandang yang masih terbuat dari kayu dan bambu (Hartina et al., 2019). Penggunaan kandang yang tidak maksimal dengan pemberian pakan pagi hari dan sore hari dengan pemberian vitamin atau obat hanya di berikan sesuai dengan pengetahuan yang peternak dapat secara otodidak (Rahmat et al., 2020). Ayam kampung juga sangat sulit untuk mendapatkan bibit yang baik dan produktivitasnya yang rendah sehingga dikhawatirkan populasi ayam kampung akan semakin menurun bahkan ayam kampung yang mempunyai sifat spesifik tersebut akan punah (Sujionohadi dan Setiawan, 2000).

Pengukuran ukuran tubuh sangat perlu dilakukan dikarenakan ukuran tubuh suatu individu merupakan satu indikator yang baik dan juga memiliki nilai korelasi yang cukup erat dengan parameter bobot hidup (Suparyanto et al., 2004). Pengukuran morfometrik juga dapat membantu proses seleksi dan perkawinan silang ternak baik antar bangsa ataupun antar jenis (Kurnianto et al., 2013). Salah satu penelitian dasar untuk menggali informasi genetik yaitu pengamatan fenotipik dengan pengukuran morfologi, seperti yang telah dilakukan beberapa peneliti pada ayam oleh (Udeh et all., 2011 dan Ojedapo et all., 2012) ; pada itik (Muzani et all., 2005) ; pada domba 
(Sumantri et al., 2007; Atmaja et al., 2012).

Oleh karena itu perlu adanya informasi ilmiah ciri khas karakteristik fenotipe pada sifat kuantitatif ayam kampung di Minahasa. Penelitian ini bertujuan untuk mengukur dan mengetahui lebih dalam karakteristik (fenotipik) sifat kuantitatif ayam kampung di Minahasa dan diharapkan dapat menjadi tambahan informasi ilmiah tentang karakter kuantitatif sebagai salah satu acuan dalam usaha pelestarian sumber daya genetic (SDG) dan untuk tujuan pengembangan ayam kampung lainnya.

\section{MATERI DAN METODE PENELITIAN}

\section{Tempat dan Waktu Penelitian}

Penelitian ini dilaksanakan di Minahasa selama 3 bulan yaitu pada bulan Desember 2019 sampai dengan bulan Februari 2020.

\section{Materi Penelitian}

Materi yang digunakan dalam penelitian ini, yaitu populasi ayam kampung jantan dan betina yang telah di pisahkan berdasarkan umur (6 bulan ke atas) dan telah mencapai dewasa kelamin yaitu sebanyak 291 ekor. Jantan 166 ekor dan betina 125 ekor. Alat dan bahan yang digunakan yaitu Jangka sorong digital, pita ukur, lembar data dan alat tulis, kamera digital dan laptop.

\section{Metode Penelitian}

Metode penelitian yang digunakan adalah metode penelitian eksplorasi dimana pengambilan data diambil langsung di lokasi dengan melakukan pengamatan langsung terhadap sifat kuantitatif serta pengukuran terhadap parameter yang diamati yang meliputi bagian tubuh: panjang femur, panjang tibia, panjang shank, lingkar shank, panjang sayap, panjang jari ketiga, tinggi jengger dan panjang paruh (Sartika, 2013; Suhardi, 2012). Kemudian dianalisis secara deskriptif berupa perhitungan rataan populasi sifat kuantitatif yang diukur $(\mu)$, simpangan baku populasi $(\sigma)$ koefisien keragaman (KK), dilanjutkan dengan analisis Korelasi dan Uji-T untuk membandingkan antara ayam kampung jantan dan betina. Analisis data mengacu pada Noor (2010). dengan rumus sebagai berikut :

$$
\begin{array}{ll}
\mu=\frac{\sum X_{i}}{\mathrm{n}} & \sigma=\sqrt{\frac{\sum\left(X_{i}-\mu\right)^{2}}{\mathrm{~N}}} \\
\mathrm{KK}=\frac{\sigma}{\mu} \mathrm{X} 100 & r_{p}=\frac{\operatorname{Cov} p}{\sigma P_{1} \sigma P_{2}}
\end{array}
$$

Keterangan :

$\mu \quad=$ Nilai rataan parameter populasi

$\sum \quad=$ Penjumlahan

$\mathrm{x}_{\mathrm{i}} \quad=$ Setiap nilai dari populasi

$\mathrm{N}=$ Jumlah parameter

$\sigma \quad=$ Standar Deviasi Populasi

KK =Koefisien Keragaman (\%)

$\mathrm{r}_{\mathrm{p}} \quad=$ Korelasi fenotipik kedua karakter yang diukur jantan dan betina

$\mathrm{P}_{1} \& \mathrm{P}_{2}=$ Karakter parameter jantan dan betina

$\sigma \mathrm{P}_{1} \sigma \mathrm{P}_{2}=$ Ragam fenotip dari karakter parameter 
$\mathrm{COV}_{\mathrm{P}}=$ Kovarian terhadap karakter Parameter

$$
\mathrm{t}=\frac{\mathrm{X}_{1}-\mathrm{X}_{2}}{\sqrt{\frac{\mathrm{s}_{1}^{2}}{\mathrm{n}_{1}}+\frac{\mathrm{s}_{2}^{2}}{\mathrm{n}_{2}}}}
$$

Keterangan :

$\mathrm{t}=$ =Nilai $\mathrm{t}$ hitung

$\mathrm{X}_{1} \quad=$ Rataan ukuran tubuh tertentu ayam jantan

$\mathrm{X}_{2} \quad=$ Rataan ukuran tubuh tertentu ayam betina

$\mathrm{S}_{1}^{2}=$ =Varians parameter ayam jantan

$\mathrm{S}_{2}^{2}=$ Varians parameter ayam betina

$\mathrm{n}_{1}=$ Jumlah parameter ayam jantan

$\mathrm{n}_{2} \quad=$ Jumlah parameter ayam betina

\section{HASIL DAN PEMBAHASAN}

\section{Gambaran Umum Kabupaten Minahasa}

Kondisi Kabupaten Minahasa merupakan daerah yang berada di pegunungan. Minahasa merupakan salah satu kabupaten yang ada di Sulawesi Utara. Pekerjaan masyarakat di Minahasa sebagian besar sebagai petani. Beternak merupakan usaha sampingan masyarakat, salah satu ternak yang dipelihara oleh masyarakat adalah ayam kampung.

\section{Sistem Pemeliharaan Ayam Kampung}

Manajemen pemeliharaan ayam kampung yang dilakukan oleh masyarakat masih sederhana. Kandang ayam masih dibuat seadanya di belakang, disamping rumah dan bahkan di kolong-kolong rumah masyarakat. Biasanya kandang digunakan pada malam hari, sedangkan pada siang hari ayam kampung dibiarkan lepas begitu saja (Rahmat et al., 2020).

\section{Sifat Kuantitatif Ayam Kampung dan Uji Perbedaan Dua Rataan dan Uji-T}

Hasil penelitian terhadap sifat-sifat kuantitatif ayam kampung menggambarkan beberapa ukuran tubuh ayam kampung di Minahasa seperti ditunjukan pada Tabel 1 . bahwa ukuran total panjang femur ayam kampung Minahasa rata-rata sebesar $123 \pm 19,760 \mathrm{~mm}$ dengan koefisien keragaman 16,065\%. Pada jantan Berdasarkan Tabel 1 dapat terlihat $125 \pm 19,820 \mathrm{~mm}$ dengan koefisien keragaman $15,856 \%$ dan $121 \pm 19,632 \mathrm{~mm}$ pada betina dengan koefisien keragaman $16,225 \%$. Berdasarkan hasil uji-t ukuran panjang femur ayam kampung antara jantan dan betina tidak berbeda. Hasil penelitian ini lebih panjang dari rata-rata ukuran ayam kampung jantan dan betina pada penelitian Saputra (2006), Subekti dan Arlina (2011), Sitanggang (2015), Permadi el al., (2020) yaitu $111,38 \mathrm{~mm}$ dan $105,49 \mathrm{~mm}$; 109,24 $\mathrm{mm}$ dan 95,39 mm ; $98 \mathrm{~mm}$; $107 \mathrm{~mm}$ dan $90 \mathrm{~mm}$.

Ukuran total panjang tibia ayam kampung Minahasa dari penelitian ini menunjukkan nilai rata-rata sebesar $131 \pm 22,205 \mathrm{~mm}$ dengan koefisien jantan $138 \pm 22,997$ dengan koefisien keragaman sebesar $16,664 \%$ dan $126 \pm 20,271 \mathrm{~mm}$ dengan koefisien keragaman 16,088\% pada 
Tabel 1. Rataan Ukuran Tubuh, Simpangan Baku, Koefisien Keragaman dan Uji-T perbandingan Ukuran Tubuh Ayam Kampung di Minahasa Berdasarkan Jenis Kelamin

\begin{tabular}{lrrrr}
\hline $\begin{array}{l}\text { Rataan Ukuran } \\
\text { Tubuh }(\mathrm{mm})\end{array}$ & \multicolumn{1}{c}{$\begin{array}{c}\text { Jantan } \\
\text { SD }\end{array}$} & $\begin{array}{c}\text { Betina } \\
(\mathrm{n}=166)\end{array}$ & \multicolumn{1}{c}{$\begin{array}{c}\text { Uji t } \\
(\mathrm{P}<0,05)\end{array}$} & \multicolumn{1}{c}{$\begin{array}{c}\text { Total } \\
(\mathrm{n}=291)\end{array}$} \\
KK $(\%)$ & & & & \\
\hline PF & $125 \pm 19,820$ & $121 \pm 19,632$ & $0,122788856^{\mathrm{ns}}$ & $123 \pm 19,760$ \\
& 15,856 & 16,225 & & 16,065 \\
PT & $138 \pm 22,997^{\mathrm{a}}$ & $126 \pm 20,271^{\mathrm{b}}$ & $0,00000744391^{* *}$ & $131 \pm 22,205$ \\
& 16,664 & 16,088 & & 16,950 \\
PTS & $113 \pm 20,896^{\mathrm{a}}$ & $103 \pm 23,526^{\mathrm{b}}$ & $0,0000727422^{* *}$ & $109 \pm 22,633$ \\
& 18,492 & 22,840 & & 20,765 \\
LS & $55 \pm 7,445^{\mathrm{a}}$ & $53 \pm 7,025^{\mathrm{b}}$ & $0,0220802403^{*}$ & $54 \pm 7,321$ \\
& 13,491 & 13,205 & & 13,476 \\
PS & 12,303 & 16,713 & & $226 \pm 32,427$ \\
& $128 \pm 28,052$ & $224 \pm 37,464$ & $0,3166435756^{\mathrm{ns}}$ & 14,326 \\
PJK & 14,828 & 16,987 & \\
& $24 \pm 6,120^{\mathrm{a}}$ & $21 \pm 7,440^{\mathrm{b}}$ & $0,00000157789^{* *}$ & $22 \pm 6,926$ \\
TJ & 25,492 & 36,270 & & 30,777 \\
& $26 \pm 4,928^{\mathrm{a}}$ & $25 \pm 4,930^{\mathrm{b}}$ & $0,048330366^{*}$ & $25 \pm 4,954$ \\
PP & 18,704 & 19,568 & & 19,162 \\
\hline
\end{tabular}

Keterangan: $\mathrm{PF}=$ panjang femur $(\mathrm{mm}), \mathrm{PT}=$ panjang tibia $(\mathrm{mm}), \mathrm{PTS}=$ panjang shank $(\mathrm{mm}), \mathrm{LS}=$ lingkar shank $(\mathrm{mm}), \mathrm{PS}=$ panjang sayap $(\mathrm{mm}), \mathrm{PJK}=$ panjang jari ketiga $(\mathrm{mm}), \mathrm{TJ}=$ tinggi jengger $(\mathrm{mm}), \mathrm{PP}=$ panjang paruh $(\mathrm{mm}), \mathrm{SD}=$ standar deviasi, $\mathrm{KK}=$ koefisien keragaman, $\mathrm{N}=$ jumlah ayam, Superskrip huruf yang berbeda $(\mathrm{a}, \mathrm{b})$ menunjukkan berbeda nyata $(\mathrm{P}<0.05)$ dan sangat berbeda nyata $(\mathrm{P}<0.01)$.

betina dimana keragaman sebesar 16,950\%.

Pada terlihat bahwa ternyata panjang tibia ayam jantan lebih panjang dibandingkan ayam betina, dan hasil uji-t menunjukkan bahwa ukuran panjang tibia ayam kampung antara jantan dan betina ternyata sangat berbeda nyata atau signifikan $(\mathrm{P}<0.01)$. Hasil penelitian ini disebabkan oleh karena perbedaan kecepatan pertumbuhan ternak satu dengan yang lain. Menurut Mufti (2003) bahwa ayam kampung jantan memiliki ukuran-ukuran tubuh lebih besar dibandingkan ayam kampung betina pada umur yang sama. Hasil penelitian ini lebih panjang dari rata-rata ukuran ayam kampung jantan pada penelitian Saputra (2006) yaitu $135,23 \mathrm{~mm}$ dan $126,42 \mathrm{~mm}$. Subekti dan Arlina (2011) rata-rata ukuran panjang tibia ayam kampung lebih pendek pada jantan dan lebih panjang pada betina yaitu $144,48 \mathrm{~mm}$ dan $125,34 \mathrm{~mm}$. Hasil penelitian ini juga lebih pendek dari ratarata ukuran ayam kampung pada penelitian Sitanggang (2015) yaitu $134 \mathrm{~mm}$.

Berdasarkan Tabel 1 juga terlihat bahwa ukuran total panjang shank ayam 
kampung Minahasa memiliki nilai rata-rata sebesar $109 \pm 22,633 \mathrm{~mm}$ dengan koefisien keragaman sebesar $20,764 \%$ yaitu pada jantan 113 $\pm 20,896 \mathrm{~mm}$ dengan koefisien keragaman sebesar 18,492\%, dan $103 \pm 23,526 \mathrm{~mm}$ pada betina dengan koefisien keragaman $22,840 \%$ dimana terlihat bahwa ternyata panjang shank ayam jantan lebih panjang dibandingkan ayam betina. Perbedaan rata-rata panjang shank ayam jantan dan betina secara statistik melalui hasil uji-t sangat berbeda nyata atau signifikan $(\mathrm{P}<0.01)$. Perbedaan dalam penelitian ini dapat disebabkan oleh lingkungan, sistem pemeliharaan dan manajemen pemeliharaan. Kusuma dan Prijono (2007) menyatakan bahwa bervariasinya ukuran tubuh ayam kampung dapat dipengaruhi oleh lingkungan pemeliharaan dan bibit yang berbeda. Hasil penelitian ini lebih panjang pada jantan dan betina pada penelitian Arlina dan Afriani (2003), Saputra (2006), Subekti dan Arlina (2011), Sitanggang (2015), Permadi et al. (2020) yaitu 108,03 $\mathrm{mm}$ dan 83,82 $\mathrm{mm}$; $107,34 \mathrm{~mm}$ dan $87,70 \mathrm{~mm} ; 103,60 \mathrm{~mm}$ dan $81,07 \mathrm{~mm} ; 87 \mathrm{~mm} ; 89 \mathrm{~mm}$ dan $72 \mathrm{~mm}$.

Dapat terlihat juga bahwa ukuran total lingkar shank ayam kampung Minahasa rata-rata sebesar $54 \pm 7,321 \mathrm{~mm}$ dengan koefisien keragaman 13,476\%. Pada jantan rata- rata $55 \pm 7,445 \mathrm{~mm}$ koefisien keragaman $13,491 \%$ dan $53 \pm 7,025 \mathrm{~mm}$ koefisien keragaman 13,205\% pada betina, dimana rata-rata lingkar shank ayam jantan lebih panjang dibandingkan ayam betina, dan melalui hasil uji-t ukuran lingkar shank ayam kampung antara jantan dan betina signifikan atau berbeda nyata $(\mathrm{P}<0.05)$. Hasil penelitian ini disebabkan oleh karena perbedaan kecepatan pertumbuhan ternak satu dengan yang lain. Permadi et al., (2020) menyatakan bahwa pertumbuhan tulang pada ayam kampung jantan lebih cepat dibandingkan dengan pertumbuhan tulang pada ayam kampung betina. Hasil penelitian ini lebih besar dari rata-rata ukuran ayam kampung pada penelitian Sitanggang (2015), Rangkuti et al. (2016) dan Permadi el al. (2020) dimana lebih kecil pada jantan dan besar pada betina yaitu sebesar $50 \mathrm{~mm} ; 12 \mathrm{~mm}$ dan $10 \mathrm{~mm} ; 57 \mathrm{~mm}$ dan $42 \mathrm{~mm}$.

Ukuran total panjang sayap ayam kampung Minahasa rata-rata sebesar $226 \pm 32,427 \mathrm{~mm}$ dengan koefisien keragaman 14,326\%. Pada jantan $228 \pm 28,052 \mathrm{~mm}$ koefisien keragaman sebesar $12,303 \%$ dan $224 \pm 37,464 \mathrm{~mm}$ pada betina dengan koefisien keragaman 16,713\%. Hasil uji-t ternyata ukuran panjang sayap ayam kampung antara jantan dan betina tidak berbeda. Hasil penelitian ini lebih panjang dari rata-rata ukuran ayam kampung jantan dan betina pada penelitian Subekti dan Arlina (2011), Permadi et al. (2020) yaitu 217,4 mm dan 196,9 mm; 
218,41 $\mathrm{mm}$ dan 188,65; $219 \mathrm{~mm}$ dan 179 $\mathrm{mm}$.

Berdasarkan Tabel 1 dapat terlihat bahwa ukuran total panjang jari ketiga ayam kampung Minahasa rata-rata sebesar $84 \pm 13,739 \mathrm{~mm}$ dengan koefisien keragaman 16,320\%. Pada jantan $81 \pm 12,065 \mathrm{~mm}$ dengan koefisien keragaman $14,828 \%$ dan $88 \pm 14,935 \mathrm{~mm}$ koefisen keragaman sebesar 16,987\% pada betina, dimana rata-rata panjang jari ketiga ayam betina lebih panjang dibandingkan ayam jantan, dan melalui hasil uji-t ternyata ukuran panjang jari ketiga ayam kampung antara jantan dan betina sangat berbeda nyata atau $(\mathrm{P}<0.01)$. perbedaan dari hasil penelitian ini dapat dipengaruhi oleh faktor lingkungan dan juga faktor genetik. Noor (2008) menyatakan bahwa sifat kuantitatif merupakan sifat yang dikontrol oleh banyak gen yang perbedaan antar fenotipenya tidak begitu jelas dan bersifat aditif dan variasi kontinyu. Biasanya hubungan antar alel yang paling umum adalah kodominan atau dominan tidak penuh. Hasil penelitian ini lebih panjang dari rata-rata ukuran ayam kampung jantan dan betina pada penelitian Subekti dan Arlina (2011), Sitanggang (2015), Permadi el al. (2020) yaitu 73,20 $\mathrm{mm}$ dan 63,52 $\mathrm{mm} ; 73,94 \mathrm{~mm}$ dan 65,76 $\mathrm{mm} ; 32 \mathrm{~mm}$; $53 \mathrm{~mm}$ dan $46 \mathrm{~mm}$.

Pada Tabel 1 juga terlihat bahwa ukuran total tinggi jengger ayam kampung Minahasa rata-rata sebesar $22 \pm 6,926 \mathrm{~mm}$ dengan koefisien keragaman 30,777\%. Pada jantan $24 \pm 6,120 \mathrm{~mm}$ memiliki koefisien keragaman $25,492 \%$ dan $20 \pm 7,440 \mathrm{~mm}$ pada betina dengan koefisien keragaman $36,270 \%$ dimana rata-rata tinggi jengger ayam jantan lebih tinggi dibandingkan ayam betina, dan melalui hasil uji-t ternyata ukuran tinggi jengger ayam kampung antara jantan dan betina sangat berbeda atau signifikan $(\mathrm{P}<0.01)$. Perbedaan hasil penelitian ini dapat disebabkan oleh karena faktor genetik dimana sama halnya dengan pendapat Herren (2000) bahwa tinggi jengger ayam kampung jantan dua kali lebih tinggi dibandingkan dengan tinggi jengger ayam kampung betina. Sifat ini merupakan salah satu ciri untuk menetukan jenis kelamin ayam. Hasil penelitian ini lebih tinggi dari rata-rata ukuran ayam kampung jantan dan betina pada penelitian Saputra (2006), Subekti dan Arlina (2011) yaitu $18,89 \mathrm{~mm}$ dan $12,74 \mathrm{~mm} ; 23,15 \mathrm{~mm}$ dan $9,84 \mathrm{~mm}$.

Berdasarkan Tabel 1 dapat terlihat juga bahwa ukuran total panjang paruh ayam kampung Minahasa rata-rata sebesar 25 44,954 mm dengan koefisien keragaman $19,162 \%$. Pada jantan $26 \pm 4,928 \mathrm{~mm}$ dengan koefisien keragaman $18,704 \%$ dan $25 \pm 4,930 \mathrm{~mm}$ pada betina koefisien keragaman 19,568\%, dimana rata-rata panjang paruh ayam jantan lebih panjang dibandingkan ayam betina, dan melalui hasil uji-t ternyata ukuran panjang paruh 
ayam kampung antara jantan dan betina berbeda atau signifikan $(\mathrm{P}<0.05)$. Perbedaan dari penelitian ini dapat disebabkan oleh suatu sifat yang bergantung pada gen yang dimiliki ternak. Noor (2008) menyatakan sifat kuantitatif yang diekspresikan merupakan pengaruh genetik, lingkungan serta interaksi genetik terhadap lingkungan. Hasil penelitian ini lebih panjang dari rata-rata ukuran ayam kampung jantan dan betina pada penelitian Mariandayani (2013), Rangkuti et al. (2016), Permadi el al. (2020) yaitu 17,42 mm dan 16,42 mm; $24 \mathrm{~mm}$ dan $22 \mathrm{~mm} ; 26$ $\mathrm{mm}$ dan $20 \mathrm{~mm}$. Sesuai dengan pendapat Pagala et al. (2015) bahwa keragaman sifat produksi hewan disebabkan oleh faktor genetic dan lingkungan. Seperti kemungkinan adanya pembauran atau pencampuran dengan gen bangsa ayam lain seperti ayam Bangkok. Brahmantiyo et al. (2006) menyatakan bahwa beberapa kesamaan pada ternak terjadi karena adanya persilangan yang dilakukan oleh peternak dengan menggabungkan beberapa bangsa ayam dengan tujuan untuk mendapatkan sifat fisiologis yang dapat bertahan hidup dalam lingkungan tersebut. Dapat diduga juga disebabkan oleh karena umur ayam dan lokasi penelitian. Brahmantiyo et al. (2003) menyatakan bahwa ternak dapat memiliki genetik yang sama hubungannya ditandai dengan adanya peta penyebaran yang berhimpitan.
Kurnianto (2010) menyatakan bahwa kategori keragaman ayam kampung dapat dibedakan menjadi tiga, yaitu tinggi $(\mathrm{KK} \geq 15 \%)$, sedang $(5 \%<\mathrm{KK}<15 \%)$ dan rendah $(\mathrm{KK} \leq 5 \%)$. Berdasarkan Tabel 1 ayam kampung di Minahasa memiliki sifat kuantitatif dengan keragaman tinggi yaitu pada panjang femur (16\%) panjang tibia (16\%) panjang shank (20\%) panjang jari ketiga (16\%) tinggi jengger (30\%) dan panjang paruh (19\%). Sifat kuantitatif dengan keragaman sedang yaitu lingkar shank (13\%) dan panjang sayap (14\%). Keragaman sangat penting untuk perannya dalam seleksi ternak karena nilainya sangat bermanfaat untuk melihat potensi keragaman dalam populasi yg menjadi landasan untuk tahap pemuliaan selanjutnya. Menurut Tantu (2007) bahwa keragaman ayam kampung dapat dijadikan dasar untuk perbaikan mutu genetik dengan melalui program seleksi.

\section{Analisis Korelasi Ukuran Tubuh Ayam Kampung Jantan dan Betina}

Koefisien korelasi antar beberapa ukuran tubuh ayam kampung jantan dan betina di Minahasa memiliki tiga kategori nilai korelasi yaitu korelasi tinggi, sedang dan rendah. Wardono et al. (2014) menyatakan bahwa angka koefisien korelasi dinyatakan positif tinggi apabila nilai antara 0,5-1,0, positif sedang $0,25-0,50$ dan positif rendah 0,05-0,25. 
Tabel 2. Koefisien Korelasi Ukuran Tubuh Ayam Kampung Jantan dan Betina di Minahasa.

\begin{tabular}{lcccccccc}
\hline & PF & PT & PTS & LS & PS & PJK & TJ & PP \\
\hline PF & & 0,702 & 0,608 & 0,640 & 0,569 & 0,368 & 0,214 & 0,164 \\
PT & 0,638 & & 0,484 & 0,455 & 0,425 & 0,393 & 0,151 & 0,108 \\
& 0,765 & & & & & & & \\
PTS & 0,774 & 0,764 & & 0,626 & 0,510 & 0,262 & 0,329 & 0,150 \\
& 0,505 & 0,386 & & & & & & \\
LS & 0,651 & 0,589 & 0,647 & & 0,661 & 0,472 & 0,321 & 0,191 \\
& 0,675 & 0,422 & 0,586 & & & & & \\
PS & 0,519 & 0,464 & 0,459 & 0,662 & & 0,438 & 0,247 & 0,159 \\
& 0,647 & 0,453 & 0,560 & 0,678 & & & \\
PJK & 0,384 & 0,477 & 0,341 & 0,570 & 0,474 & & 0,217 & 0,327 \\
& 0,335 & 0,236 & 0,328 & 0,479 & 0,460 & & & 0,166 \\
TJ & 0,266 & 0,212 & 0,289 & 0,305 & 0,358 & 0,265 & & \\
& 0,225 & 0,249 & 0,287 & 0,299 & 0,144 & 0,319 & & \\
PP & 0,208 & 0,275 & 0,141 & 0,130 & 0,122 & 0,273 & 0,007 & \\
\hline Keteran & 0,134 & $-0,010$ & 0,112 & 0,245 & 0,188 & 0,472 & 0,292 & \\
\hline
\end{tabular}

Keterangan: Angka yang berada diatas diagonal adalah nilai korelasi ayam kampung jantan dan betina diminahasa dan yang berada di bawah garis diagonal adalah nilai korelasi masing- masing jantan dan betina (huruf miring).

Tabel 2. menggambarkan hasil penelitian koefisien korelasi ukuran tubuh ayam kampung jantan dan betina di Minahasa. Koefisien korelasi ukuran tubuh ayam kampung jantan di Minahasa seperti yang terlihat pada Tabel 2 yaitu ukuran PF ayam kampung jantan berkorelasi tinggi dengan PT, PTS, LS, PS sebesar 0,638 mm; 0,774 $\mathrm{mm} ; \quad 0,651 \mathrm{~mm} ; 0,519 \mathrm{~mm}$. Berkorelasi sedang dengan PJK dan TJ sebesar 0,384 $\mathrm{mm} ; \quad 0,266 \mathrm{~mm}$. Ukuran tubuh PT berkorelasi tinggi dengan PTS, LS sebesar 0,764 $\mathrm{mm} ; 0,589 \mathrm{~mm}$ dan berkorelasi sedang dengan PS, PJK dan PP sebesar 0,464 mm; 0,477 mm; 0,275 mm. Ukuran tubuh PTS ayam kampung jantan berkorelasi tinggi dengan LS sebesar 0,647 $\mathrm{mm}$. Berkorelasi sedang dengan PS, PJK dan TJ sebesar 0,459 mm ; 0,341 mm ; 0,289 mm. LS berkorelasi tinggi dengan PS ; PJK sebesar 0,$662 ; 0,570$ dan berkorelasi sedang dengan TJ sebesar 0,305 mm. Ukuran tubuh PS ayam kampung jantan berkorelasi sedang dengan PJK, TJ sebesar 0,474 mm ; 0,358 mm. Koefisien korelasi ukuran tubuh ayam kampung betina di Minahasa seperti yang terlihat pada Tabel 2 yaitu ukuran PF ayam kampung betina berkorelasi tinggi dengan PT, PTS, LS, PS, sebesar 0,765 mm; 0,505 mm; 0,675 mm; 0,647 mm. Berkorelasi sedang dengan PJK dan TJ sebesar 0,335 mm; 0,225 mm. Ukuran PT ayam kampung betina berkorelasi sedang dengan PTS, LS, PS, PJK, TJ sebesar 0,386 $\mathrm{mm} ; 0,422 \mathrm{~mm} ; 0,453 \mathrm{~mm} ; 0,236 \mathrm{~mm}$; 0,249 mm. Ukuran PTS ayam kampung 
betina berkorelasi tinggi dengan LS, PS sebesar 0,586 mm; 0,560 mm. Berkorelasi sedang dengan PJK, TJ sebesar 0,328 mm; 0,287 mm. Ukuran LS ayam kampung betina berkorelasi tinggi dengan PS sebesar 0,678 $\mathrm{mm}$ dan berkorelasi sedang dengan PJK, TJ, PP sebesar 0,479 mm; 0,299 mm; 0,245 mm. Ukuran PS ayam kampung betina berkorelasi sedang dengan PJK sebesar 0,460 $\mathrm{mm}$ dan PJK berkorelasi sedang dengan TJ, PP sebesar 0,319 mm; 0,472 mm. Koefisien korelasi ukuran tubuh dari ayam $\mathrm{k}$ ampung jantan dan betina di Minahasa seperti yang terlihat pada Tabel 2 pada angka yang berada diatas garis diagonal adalah nilai korelasi total. PF berkorelasi tinggi dengan PT, PTS, LS, PS sebesar 0,702 mm; 0,608 mm; 0,640 mm; $0,569 \mathrm{~mm}$; dan berkorelasi sedang dengan PJK sebesar 0,368 mm. Nilai korelasi total PT berkorelasi sedang dengan PTS, LS, PS, PJK sebesar 0,484 mm; 0,455 mm; 0,425 $\mathrm{mm} ; 0,393 \mathrm{~mm}$. PTS berkorelasi tinggi dengan LS dan PS sebesar 0,626 mm; 0,510 $\mathrm{mm}$ dan berkorelasi sedang dengan PJK, TJ sebesar 0,262 mm; 0,329 mm. LS berkorelasi tinggi dengan PS sebesar 0,661 mm dan berkorelasi sedang dengan PJK, TJ sebesar $0,472 \mathrm{~mm} ; \quad 0,321 \mathrm{~mm}$. PS berkorelasi sedang dengan PJK sebesar 0,438 $\mathrm{mm}$. PJK berkorelasi sedang dengan TJ dan PP sebesar 0,217 mm; 0,327 mm.

\section{KESIMPULAN}

Sifat-sifat kuantitatif ayam kampung jantan dan betina di Minahasa masih sangat beragam dan berkorelasi dari tinggi sampai dengan rendah.

\section{DAFTAR PUSTAKA}

Arlina, F dan T. Afriani. 2003. Karakteristik genetic eksternal dan morfologi ayam kampung. Jurnal Peternakan dan Lingkungan 9(2): 15.

Atmaja, D.S., E. Kurnianto, B. Sutiyono. 2012. Ukuran-ukuran tubuh domba betina beranak tunggal dan kembar di kecamatan Bawen dan Jambu kabupaten Semarang. Animal Agric J. 1(1):123-133.

Brahmantiyo, B., L. H. Prasetyo, A. R. Setioko, dan R. H. Mulyono. 2003. Pendugaan jarak genetik dan faktor peubah pembeda galur itik (Alabio, Bali, Khaki Campbell, Mojosari dan Pegagan) melalui analisis morfometrik. Jurnal Ilmu Ternak Veteriner 8 (1): 1-7.

Brahmantiyo, B., R. H. Mulyono dan A. Sutisna. 2006. Ukuran dan bentuk itik pekin (Anasplatyrhynchos), entok impor dan entok local (Cairina moschata). Lokakarya Nasional Pengelolaan dan perlindungan Sumber Daya Genetik di Indonesia: Manfaat Ekonomi untuk mewujudkan ketahanan nasional. Bogor, 20 Desember 2006. Balai Penelitian Ternak, Bogor. 266272. 
Hartina, S. B., G. J. V. Assa, F. J. Nangoy, C. L. K. Sarajar, Meis Nangoy. 2019. Infestasi kutu pada ayam kampung (Gallus gallus domestic) di Desa Tolok Kecamatan Tompaso Kabupaten Minahasa. Zootec 39(2):451-458.

Herren, R. 2000. The Science of Animal Agriculture. 2. Edition. Delmar, New York.

Kurnianto, E., 2009. Pemuliaan Ternak. Cetakan Pertama. Graha Ilmu Yogyakarta.

Kurnianto, E., S. Sutopo, E. Purbowati, E.T. Setiatin, D. Samsudewa and T. Permatasari. 2013. Multivariate analysis of morphological traits of local goats in Central JavaIndonesia. Iranian J. App. Anim. Sci. 3 (2):361-367.

Kusuma, D. dan N. S. Prijono. 2007. Keanekaragaman Sumber Daya Hayati Ayam Lokal Indonesia: Manfaat dan Potensi. LIPI Press. Jakarta.

Mariandayani, H. N., D.D. Solihin, S. Sulandari, dan C. Sumantri, 2013. Keragaman fenotipik dan pendugaaan jarak genetik pada ayam lokal dan ayam broiler menggunakan analisis morfologi. Jurnal Veteriner 14(4):475-484.

Mufti, R. 2003. Studi ukuran dan bentuk tubuh ayam kampung, ayam pelung dan persilangannya. Skripsi. Fakultas Peternakan. Institut Pertanian Bogor, Bogor.

Muzani, A., Brahmantiyo, B., Sumantri, C., Tapyadi, A. 2005. Pendugaan jarak genetik pada itik Cihateup Cirebon dan Mojosasari. Media Peternakan. 28 (3) : 109-116.
Nataamijaya, A. G. 2000. The native chicken of Indonesia. Bulletin Plasma Nutfah 6(1):1-6.

Noor, R. R. 2008. Genetika ternak. Penebar Swadaya, Jakarta.

Noor, R. R. 2010. Genetika ternak. Penebar Swadaya, Jakarta.

Ojedapo, LO., Amao, SR., Ameen, SA., Adedeji, TA., Ogundipe, RI., Ige, AO. 2012. Prediction of body weight and other linear body measurement og two commercial layer strain chickens. Asian J of Anim Sci. 1-10.

Pagala, M. A., A. M. Tasse, \& N. Ulupi. 2015. Association of cGH EcoRV Gene with Production in Tolaki Chicken. IJSBAR 24(7):88-95.

Permadi, A. N. N., E. Kurnianto dan Sutiyono. 2020. Karakteristik morfometrik ayam kampung jantan dan betina di Desa Tirtomulyo Kecamatan Plantungan, Kabupaten Kendal, Jawa Tengah. Jurnal Peternakan Indonesia 22 (1): 11-20.

Rahmat, Y., E. Wantasen, A. H. S. Salendu, P. O. V. Waleleng. 2020. Analisis pendapatan peternakan ayam buras yang dipelihara secara extensif di Kecamatan Dimembe. Zootec 40(1)160-171.

Rangkuti, N.A. 2016. Identifikasi morfometriks dan jarak genetik ayam kampung di Labuhanbatu Selatan. Jurnal Peternakan Intergratif. 3 (1) : 96-119.

Saputra, H. 2006. Penampilan kuantitatif ayam kampung pada pemeliharaan ekstensif di Kecamatan Kuranji Kota Padang. Skripsi. Fakultas Peternakan Universitas Andalas, Padang. 
Sartika, T. 2013. Perbandingan morfometrik ukuran tubuh ayam KUB dan Sentul melalui pendekatan analisis diskriminan. Seminar Nasional Teknologi Peternakan dan Veteriner. Medan, 3-4 September 2013. Puslitbang Peternakan, Medan. 561-570.

Sartika, T., S. Iskandar, dan B. Tiesnamurti. 2016. Sumberdaya Genetik ayam Lokal Indonesia dan Prospek Pengembangannya. IAARD Pr, Jakarta.

Sitanggang, E.N., Hasnudi, dan Hamdan. 2015. Keragaman sifat kualitatif dan morfometrik antara ayam kampung, ayam Bangkok, ayam Katai, ayam Birma, ayam Bagon dan Magon di Medan. Jurnal Peternakan Integratif. Vol. 3 No. 2 : 167-189.

Subekti, K dan F. Arlina. 2011. Karakteristik genetik eksternal ayam kampung di Kecamatan Sungai Pagu Kabupaten Solok Selatan. Jurnal Ilmiah Ilmu-ilmu Peternakan 14(2):74-86.

Suhardi, 2012. Identifikasi karakteristik morfologi ayam local khas dayak dari Kabupaten Berau, Kalimantan Timur. Jurnal Teknologi Pertanian $7(2): 81-86$.

Sujionohadi, K. dan A. I. Setiawan. 2000. Ayam Kampung Petelur. Penebar Swadaya, Jakarta.

Sumantri, C., A. Einstiana, J.F. Salamena, J. Inounu. 2007. Keragaman dan hubungan phylogenic antar domba local di Indonesia melalui pendekatan analisis morfologi. JITV 12(1):42-54.

Suparyanto, A., H. Martojo, P.S. Hardjosworo, L.H. Prasetyo. 2004. Kurva pertumbuhan morfologi itik betina hasil silang antara Peking dengan Mojosari putih. Jurnal Ilmu Ternak dan Veteriner 9(2):87-97.

Tantu, R. Y. 2007. Fenotipe dan Genotipe Ayam Hutan Merah (Gallus gallus) dan Ayam Kampung (Gallus Domesticus) di Watutela dan Ngatabaru Sulawesi Tengah. Thesis. Program Studi Pascasarjana Institut Pertanian Bogor. Bogor.

Udeh, I., J.O. Isikwenu, G. Ukughere. 2011. Performance characteristics and prediction of bodyweight using linear body measurements in four strains of broiler chickens. Int. J. Anim. Veter. Adv. 3(1):44-46.

Wardono, H. P., C. Sugihono, H. Kusnadi, dan Suprijono. 2014. Korelasi antara beberapa kriteria peubah produksi pada ayam buras. Balai Pengkajian Teknologi Pertanian (BPTP) Maluku Utara. 